This document was prepared in conjunction with work accomplished under Contract No. DE-AC09-96SR18500 with the U. S. Department of Energy.

\title{
DISCLAIMER
}

This report was prepared as an account of work sponsored by an agency of the United States Government. Neither the United States Government nor any agency thereof, nor any of their employees, nor any of their contractors, subcontractors or their employees, makes any warranty, express or implied, or assumes any legal liability or responsibility for the accuracy, completeness, or any third party's use or the results of such use of any information, apparatus, product, or process disclosed, or represents that its use would not infringe privately owned rights. Reference herein to any specific commercial product, process, or service by trade name, trademark, manufacturer, or otherwise, does not necessarily constitute or imply its endorsement, recommendation, or favoring by the United States Government or any agency thereof or its contractors or subcontractors. The views and opinions of authors expressed herein do not necessarily state or reflect those of the United States Government or any agency thereof. 


\section{IN-TANK PEROXIDE OXIDATION PROCESS FOR THE DECOMPOSITION OF TETRAPHENYLBORATE IN TANK 48H}

D. P. Lambert

T. B. Peters

S. D. Fink

April 2005

Waste Processing Technology Section

Savannah River National Laboratory

Aiken, SC 29808

Prepared for the U.S. Department of Energy under Contract Number DEAC09-96SR18500

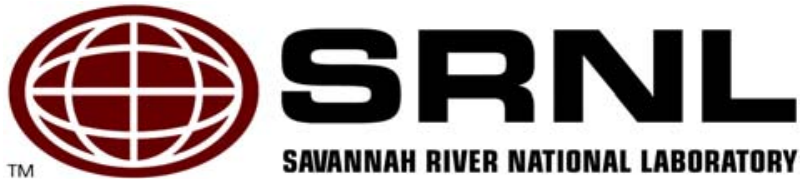


This page was intentionally left blank 
Key Words:

Tank $48 H$

Cesium

Tetraphenylborate

Retention: Permanent

\section{IN-TANK PEROXIDE OXIDATION PROCESS FOR THE DECOMPOSITION OF TETRAPHENYLBORATE IN TANK 48H}

D. P. Lambert

T. B. Peters

S. D. Fink

April 2005

Waste Processing Technology Section Savannah River National Laboratory

Aiken, SC 29808 
This page was intentionally left blank 


\section{EXECUTIVE SUMMARY}

Tank 48H return to service is critical to the processing of high level waste (HLW) at the Savannah River Site (SRS). Tank $48 \mathrm{H}$ currently holds legacy material containing organic tetraphenylborate (TPB) compounds from the operation of the In-Tank Precipitation process. The TPB was added during an in-tank precipitation process to removed soluble cesium, but excessive benzene generation curtailed this treatment method. This material is not compatible with the waste treatment facilities at SRS and must be removed or undergo treatment to destroy the organic compounds before the tank can be returned to routine Tank Farm service. Tank 48H currently contains $\sim 240,000$ gallons of alkaline slurry with approximately 19,000 kg (42,000 lb) of potassium and cesium tetraphenylborate (KTPB and CsTPB).

Out of Tank processing of the Tank $48 \mathrm{H}$ has some distinct advantages as aggressive processing conditions (e.g., high temperature, low $\mathrm{pH}$ ) are required for fast destruction of the tetraphenylborate. Also, a new facility can be designed with the optimum materials of construction and other design features to allow the safe processing of the Tank $48 \mathrm{H}$ waste. However, it is very expensive to build a new facility. As a result, an in-tank process primarily using existing equipment and facilities is desirable. Development of an in-tank process would be economically attractive. Based on success with Fenton's Chemistry (i.e., hydrogen peroxide with an iron or copper catalyst to produce hydroxyl radicals, strong oxidation agents), testing was initiated to develop a higher $\mathrm{pH}$ oxidation process that could be completed in-tank.

Two experiments determined the effectiveness of copper catalyzed peroxide oxidation (potential in-tank processes) at $\mathrm{pH} 11$ and $\mathrm{pH}$ 14. These experiments examined the extent of tetraphenylborate decomposition at $\mathrm{pH} 11$ and 14 with simulated Tank $48 \mathrm{H}$ waste. These experiments measured benzene and oxygen throughout the reactions and determined the decomposition products at the completion of the reaction. The equipment allowed accurate temperature and purge gas control, good mixing, $\mathrm{pH}$ and off-gas composition monitoring, and controlled addition of hydrogen peroxide.

The $\mathrm{pH} 11$ experiment led to complete (i.e., > 99.8\%) and fast TPB decomposition (i.e., complete in $<3$ weeks), while providing complete oxidation of TPB decomposition byproducts, including benzene. The processing scheme leads to an approximately $83 \%$ increase in waste volume. Total processing time is expected to be less than six months.

The $\mathrm{pH} 14$ experiment led to a slower TPB decomposition rate - approximately 15\% decomposition in 9 weeks. The volume roughly doubled in the nine weeks of testing so this process is not feasible in Tank $48 \mathrm{H}$ without a better catalyst system.

An estimate of corrosion rate, using the carbon steel reaction vessel as a large corrosion coupon, was completed after the experiments were complete. The general corrosion rate equaled 3.7 mil/year at $\mathrm{pH} 11$ and $1.6 \mathrm{mil} / \mathrm{year}$ at $\mathrm{pH} 14$. The corrosion rate appears "manageable" based on general corrosion rates. Corrosion can likely be further mitigated through the addition of a corrosion control inhibitor (nitrite) during processing while minimizing the reaction temperature and reaction duraration.

Several issues remain which must be resolved prior to implementation:

1. The $\mathrm{pH} 11$ test used a Tank $48 \mathrm{H}$ waste simulant. Testing is needed with Tank $48 \mathrm{H}$ waste to verify similar behavior for the actual waste. 
2. Earlier corrosion testing with Tank $48 \mathrm{H}$ simulant at an extremely fast hydrogen peroxide addition rate identified pitting of carbon steel as a potential issue. ${ }^{1}$ That report recommended more realistic corrosion testing to determine the significance of pitting while processing. Corrosion measurements should occur at the milder conditions proposed based on these experimental results.

3. The single successful test at $\mathrm{pH} 11$ was completed at a single peroxide addition rate.

Additional testing is recommended to optimize the processing conditions and to explore the robustness of the processing window. 


\section{TABLE OF CONTENTS}

1 EXECUTIVE SUMMARY iv

TABLE OF CONTENTS $\quad$ vi

TABLE OF CONTENTS Vi

LIST OF FIGURES $\quad$ vii

LIST OF TABLES $\quad$ vii

LIST OF ACRONYMS $\quad$ viii

2 INTRODUCTION AND BACKGROUND 1

2.1. Project Objectives $\quad 1$

2.2. Background
2.12

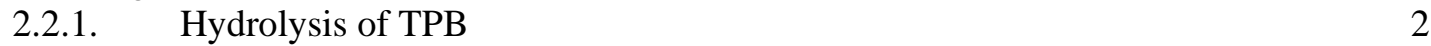

2.2.2. $\quad$ Peroxide Assisted Oxidation of TPB 2

3 APPROACH 3

3.1. Experimental Plans 3

3.1.1 Simulant Preparation 3

3.1.2 Lab-scale Instrumented Demonstrations Performed in Controlled Reactor with Simulated Tank 48H Waste

4 RESULTS

4.1. TPB Decomposition $r$

$\begin{array}{lll}4.1 .1 & \text { HPLC } & 5\end{array}$

$\begin{array}{lll}4.1 .2 & \mathrm{~K}, \mathrm{~B} \text { ingrowth } & 5\end{array}$

$\begin{array}{ll}\text { 4.1.3 HPLC } & 6\end{array}$

4.1.4 Semivolatile and Volatile Organic Analyses $\quad 7$

4.1.5 Total Organic Carbon (TOC)/Total Inorganic Carbon (TIC) 7

$\begin{array}{lll}\text { 4.1.6 Ion Chromatography (IC) Anions } & 7\end{array}$

$\begin{array}{llr}4.1 .7 & \text { Filtrate } \mathrm{pH} & 8\end{array}$

4.2. Off-gas Measurements $r$

4.2.1 Benzene Analysis $\quad 9$

$\begin{array}{ll}4.2 .2 & 11\end{array}$

4.3. Impact of Copper Addition 12

$\begin{array}{lr}\text { 4.4. Corrosion Testing } & 14\end{array}$

$\begin{array}{lr}\text { 4.5. Mass Balance } & 16\end{array}$

$\begin{array}{lr}\text { 4.6. Carbon Balance } & 17\end{array}$

5 CONCLUSIONS 18

6 REFERENCES 19 


\section{LIST OF FIGURES}

Figure 3.1 - Lab-scale Instrumented Demonstration ........................................................................... 4

Figure 4.1 - pH Profile Throughout pH 14 Experiment ............................................................................ 9

Figure 4.2 - Benzene Concentration During pH 11 Experiment ............................................................ 10

Figure 4.3 - Benzene Concentration during Portion of pH 14 Experiment.............................................. 11

Figure 4.4 - Oxygen Concentration during Experiments ................................................................ 12

Figure 4.5 - pH 11 Experiments Calculated TPB Destruction and Benzene Concentration ......................13

Figure 4.6 - Oxygen Concentration after Addition of 467 mg/L Copper Catalyst.................................... 14

Figure 4.7 - pH 11 Corrosion Test Data for Multiple Soaks with Clarke’s Solution ................................16

\section{LST OF TABLES}

Table 4.1 - TPB Decomposition Based on Results of pH 11 Filtrate and Slurry Samples (10-28-

04)

Table 4.2 - TPB Decomposition Based on Results of pH 14 Filtrate and Slurry Samples (10-2804)

Table 4.3 - HPLC Analyses of 13 common TPB decomposition byproducts ........................................... 6

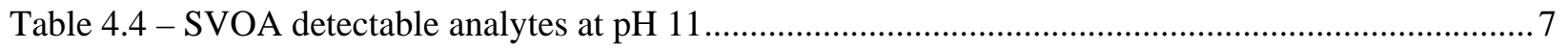

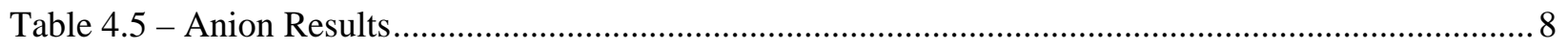

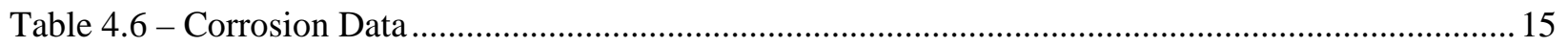

Table 4.7 - Volume Balance for pH 11 Experiment................................................................................ 17

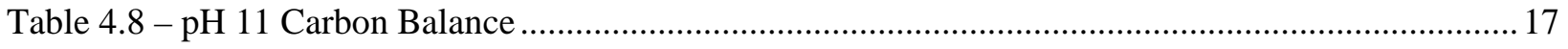




\section{LIST OF ACRONYMS}

$\begin{array}{ll}\text { 1PB } & \text { phenylboronic acid } \\ \text { 2PB } & \text { diphenylborinic acid } \\ \text { 3PB } & \text { triphenylborane } \\ \text { 4PB } & \text { tetraphenylborate } \\ \text { ADS } & \text { Analytical Development Section } \\ \text { B } & \text { boron } \\ \text { Cs } & \text { cesium } \\ \text { CsTPB } & \text { cesium tetraphenylborate } \\ \text { DOE } & \text { Department of Energy } \\ \text { GC } & \text { Gas Chromatograph } \\ \mathrm{H}_{2} \mathrm{O}_{2} & \text { hydrogen peroxide } \\ \mathrm{HLW} & \text { High Level Waste } \\ \mathrm{HPLC} & \text { High Performance Liquid Chromatography } \\ \text { ICP-ES } & \text { Inductively Coupled Plasma - Emissions Spectroscopy } \\ \text { K } & \text { potassium } \\ \text { KTPB } & \text { potassium tetraphenylborate } \\ \text { NaTPB } & \text { sodium tetraphenylborate } \\ \text { ORNL } & \text { Oak Ridge National Laboratory } \\ \text { SRNL } & \text { Savannah River National Laboratory } \\ \text { TPB } & \text { tetraphenylborate } \\ \text { WPTS } & \text { Waste Processing Technology Section }\end{array}$




\section{INTRODUCTION AND BACKGROUND}

Tank $48 \mathrm{H}$ return to service is critical to the processing of HLW at SRS. Tank $48 \mathrm{H}$ is needed to serve as the feed tank for the Actinide Removal Process. Closure Business Unit management has the goal of returning Tank 48H to routine service by as soon as practicable but no later than January 2009.

Tank $48 \mathrm{H}$ currently holds legacy material containing organic tetraphenylborate compounds from the operation of the In-Tank Precipitation process. This material is not compatible with the waste treatment facilities at SRS and must be removed or undergo treatment to destroy the organic compounds before the tank can be returned to Tank Farm service. Tank $48 \mathrm{H}$ currently contains $\sim 240,000$ gallons of alkaline slurry with potassium and cesium tetraphenylborate solids. The main radioactive component in Tank $48 \mathrm{H}$ is ${ }^{137}$ Cs.

The tetraphenylborate was added to Tank $48 \mathrm{H}$ during the demonstration and startup of the In-Tank Precipitation Facility. The original operation plan included destruction of TPB by a copper-catalyzed, acid hydrolysis process in the Salt Cell in the Defense Waste Processing Facility (DWPF). After the shutdown of the In-Tank Precipitation Process and the DWPF Salt Cell, no process exists for the destruction of the organic in Tank $48 \mathrm{H}$. The KTPB is currently safely stored in Tank $48 \mathrm{H}^{1}$. Tank $48 \mathrm{H}$ is planned to serve as the feed tank for the SRS Alpha Removal Process and contains 1.3 million gallons of usable waste storage space.

In FY 2002, a team evaluated processing options that would return Tank $48 \mathrm{H}$ to routine Tank Farm service. ${ }^{2}$ The team used a Systems Engineering approach to evaluate the alternatives and make a recommendation to management. The group evaluated 40 options and narrowed these down to 15 options using the evaluation criteria. A task plan ${ }^{3}$ detailed the experimental evaluation of these processing options using simple, laboratory scale testing with simulants. Most of the processing focused on three possible decomposition schemes: namely, catalysts, oxidants, and acids.

In FY 2003, a number of research efforts focused on developing processing schemes to decompose tetraphenylborate. Testing of Hydrolysis, Catalyzed Hydrolysis, ${ }^{4}$ and Steam Reforming ${ }^{5,6}$ received funding from the Tank 48H Disposition Project. The Department of Energy (DOE) Office of Cleanup Technology (EM-21) also directly funded studies on Fenton's chemistry ${ }^{7,8,9}$ for treatment of the waste.

This work extends the EM-21 funded work of FY03. Research in FY03 and FY04 responded to a proposal to destroy the organic in Tank $48 \mathrm{H}$ using Fenton's Reagent. ${ }^{10}$ The EM-21 testing is covered by an earlier report. ${ }^{11}$ The EM-21 research examined copper hydrolysis and peroxide oxidation processing strategies for organic destruction in-tank but testing failed to meet the Tank $48 \mathrm{H}$ destruction efficiency of 2.2-7.7 mg/L/hr equivalent TPB decomposition (2-7 mg/L/hr equivalent benzene generation) to achieve TPB decomposition in Tank $48 \mathrm{H}$ in less than one year.

This testing with non-radioactive simulant of Tank $48 \mathrm{H}$ waste determined the rate and extent of tetraphenylborate decomposition as well as the rate and type of potassium tetraphenylborate off-gas and liquid decomposition products for the Fenton's reaction chemistry. This report documents the results.

\subsection{Project Objectives}

The main objective of the research is to develop processing conditions for safe destruction of the organic present in Tank $48 \mathrm{H}$ thereby allowing return of routine high level waste service in Tank $48 \mathrm{H}$. This study

\footnotetext{
${ }^{1}$ Tank $48 \mathrm{H}$ uses an air blanket to actively purge the tank vapor space. Tank $48 \mathrm{H}$ has two independent nitrogen purge systems that could be activated if needed to control flammability.
} 
used simulated waste to examine proposed processing conditions. Other testing in FY04 with Tank $48 \mathrm{H}$ simulant ${ }^{12}$ and Tank $48 \mathrm{H}$ waste ${ }^{13,14}$ failed to find suitable processing conditions using catalyzed thermal hydrolysis.

\subsection{Background}

Most TPB decomposition processes form benzene as a byproduct. The potential for benzene production complicates the safe operation of any process for destroying the TPB in Tank $48 \mathrm{H}$. Benzene is flammable at concentrations between 1.2 and 7.8 volume $\%$ in air $^{15}$. Because of benzene's volatility, a flammable mixture of benzene and air is easily formed. Benzene is also a carcinogen with an OSHA Permissible Exposure Limit of 1 part per million ${ }^{16}$. The combination of potential flammability and toxicity makes benzene control a critical parameter to solve. Unresolvable issues resulting from higher than expected benzene production from TPB decomposition led to the eventual shutdown of the In-Tank Precipitation Facility in 1998.

\subsubsection{Hydrolysis of TPB}

Hydrolysis of the tetraphenylborate anion proceeds through a series of sequential reactions that ultimately must convert phenylboronic acid to boric acid and benzene (or other organic byproducts) to achieve complete conversion. The overall reaction is summarized below. There are dozens of postulated reactions ${ }^{17}$ for producing the organic byproducts typical of acid hydrolysis reactions, but these are omitted for brevity.

$$
\mathrm{B}\left(\mathrm{C}_{6} \mathrm{H}_{5}\right)_{4}{ }^{-}+4 \mathrm{H}_{2} \mathrm{O} \rightarrow 4 \mathrm{C}_{6} \mathrm{H}_{6}+\mathrm{B}(\mathrm{OH})_{4}^{-} \quad[1]
$$

\subsection{2. $\quad$ Peroxide Assisted Oxidation of TPB}

Processing that completely oxidizes TPB to carbon dioxide and water is advantageous as it will minimize or eliminate the benzene hazards as well as organic byproducts. Fenton's Reagent, a combination of hydrogen peroxide with typically an iron catalyst at $\mathrm{pH} 3-5$, is used to treat a variety of industrial wastes containing a range of toxic organic compounds (e.g., phenols, formaldehyde, and complex wastes derived from dyestuffs, pesticides, wood preservatives, plastics additives, and rubber chemicals). The process has been applied to wastewaters, sludges, and contaminated soils. ${ }^{18}$ Use of Fenton's Reagent has solved a number of environmental problems involving the destruction of organic contaminants in soil and groundwater including a collaborative effort between Geo-Cleanse International, Inc., and WSRC in 1997. ${ }^{19}$ However, Fenton's Reagent requires a $\mathrm{pH}$ of 3-5 for optimal decomposition. Since a reaction at pH 3-5 would be too corrosive for a carbon steel waste tank, the combination of the right catalyst with hydrogen peroxide at a $\mathrm{pH}$ above 10.3 is desirable.

The overall reactions for the tetraphenylborate ion and phenol are shown below. One of the prime reasons $\mathrm{H}_{2} \mathrm{O}_{2}$ is advantageous is that it leads to benign reaction products (i.e., water and carbon dioxide). Based on these proposed reactions, 60 moles of $\mathrm{H}_{2} \mathrm{O}_{2}$ is required per mole of tetraphenylborate and 14 moles of $\mathrm{H}_{2} \mathrm{O}_{2}$ is required per mole of phenol. The feed contained 0.035 moles of TPB and 0.0085 moles of phenol. As a result, 2.07 moles of $\mathrm{H}_{2} \mathrm{O}_{2}$ is required to destroy the TPB and 0.085 moles of $\mathrm{H}_{2} \mathrm{O}_{2}$ is required to destroy phenol (for a total of $125 \mathrm{~mL}$ of peroxide). Minimum dilution is $114 \mathrm{~mL}$ for $600 \mathrm{~mL}$ of slurry or $19 \%$. Note that excess peroxide is generally required for efficient reaction rates.

$$
\begin{aligned}
& \mathrm{B}\left(\mathrm{C}_{6} \mathrm{H}_{5}\right)_{4}{ }^{-}+60 \mathrm{H}_{2} \mathrm{O}_{2} \rightarrow 24 \mathrm{CO}_{2}+70 \mathrm{H}_{2} \mathrm{O}+\mathrm{BO}_{2}^{-} \\
& \mathrm{C}_{6} \mathrm{H}_{5} \mathrm{OH}+14 \mathrm{H}_{2} \mathrm{O}_{2} \rightarrow 6 \mathrm{CO}_{2}+17 \mathrm{H}_{2} \mathrm{O}
\end{aligned}
$$




\section{APPROACH}

The equipment and methods used in the SRNL testing is described in our laboratory notebook. ${ }^{20}$ This $^{2}$ research used protocols of an earlier study that examined copper catalysis but added on-line gas chromatography in lieu of infrared spectroscopy for vapor analyses. Using the existing equipment configuration eliminated any significant costs for starting the task.

\subsection{Experimental Plans}

Personnel conducted two experiments to determine the TPB degradation under proposed processing conditions. The equipment and methods for completing the testing is described below.

\subsubsection{Simulant Preparation}

All the experiments used full strength Tank $48 \mathrm{H}$ simulant obtained from prior studies. The simulants were prepared as part of a task to use thermal hydrolysis to decompose tetraphenylborate. ${ }^{21}$ Those earlier experiments showed minimal decomposition post acidification $(<5 \%)$ of the organic. The simulants used in the prior $\mathrm{pH} 11$ hydrolysis tests were combined together to form the slurry feed for the $\mathrm{pH} 11$ experiment. The simulants used in the prior $\mathrm{pH} 14$ hydrolysis tests were combined together to form the slurry feed for the $\mathrm{pH} 14$ experiment. No new simulant was prepared for these tests.

\subsubsection{Lab-scale Instrumented Demonstrations Performed in Controlled Reactor with Simulated Tank 48H Waste}

The program included two "Lab-scale Instrumented Demonstrations" of key stages of the reaction. These two demonstrations were performed at slightly larger scale and in "instrumented" equipment to better understand the chemistry. Note the setup existed from the previous thermal hydrolysis studies. The Labscale Instrumented Demonstrations focused on TPB decomposition and off-gas generation.

Figure 3.1 is a photograph of the equipment. Technicians added the solutions to a 1-Liter carbon steel vessel with glass lid. Personnel metered the hydrogen peroxide using a syringe pump. A pH probe monitored the $\mathrm{pH}$ during the reaction. A $15.6 \mathrm{cc} / \mathrm{min}$ nitrogen and $4.9 \mathrm{cc} / \mathrm{min}$ air purge was maintained to duplicate the Tank $48 \mathrm{H}$ nitrogen purge with tank air inleakage. The off-gas was monitored during these demonstrations using an Agilent micro Gas Chromatograph (GC) for benzene and oxygen. [The GC was obtained for another task but used for this experiment as part of its initial checkout.] 


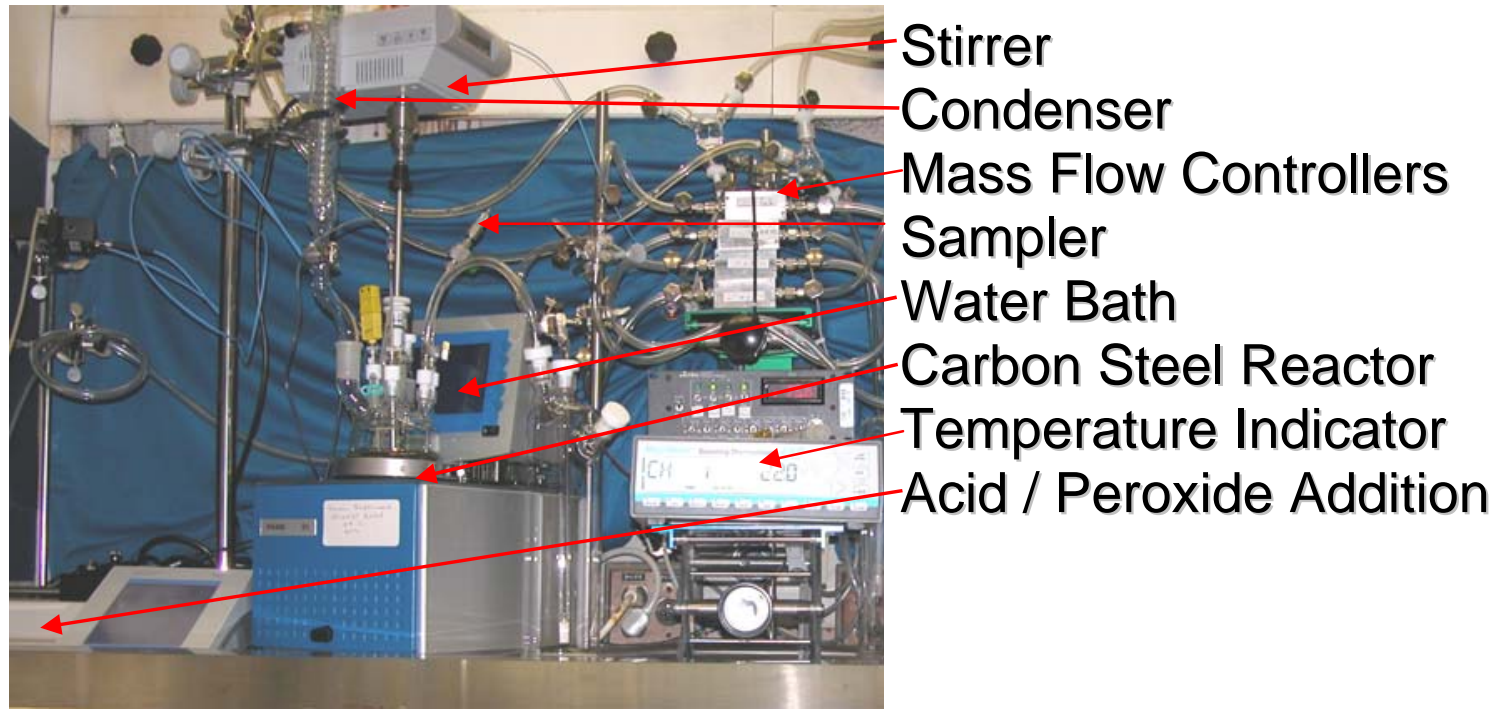

Figure 3.1 - Lab-scale Instrumented Demonstration

Technicians completed two tests in parallel lab-scale instrumented demonstrations. Each test contained $600 \mathrm{~mL}$ of Tank $48 \mathrm{H}$ simulant contained in the 1-liter carbon steel vessel. They added $24 \mathrm{mg} / \mathrm{L}$ of cupric sulfate to the simulant before the peroxide addition began and added $560 \mathrm{mg} / \mathrm{L}$ of cupric sulfate on October 8, 2005, approximately three weeks into testing. The slurry was unheated for the first week, and then the temperature was increased and held first at $35^{\circ} \mathrm{C}$, then $45^{\circ} \mathrm{C}$, then $55^{\circ} \mathrm{C}$ and finally $75^{\circ} \mathrm{C}$. Each vessel was sampled at 4 hours, 8 hours, 24 hours, 48 hours, 96 hours, 7 days and two to three times each week until the completion of the test. Each sample was filtered and archived. Approximately six weeks into testing, technicians collected a final slurry sample.

A subset of these samples was selectively analyzed for soluble K and B by ICP-ES to determine the TPB decomposition rate and estimate the benzene generation rate. Personnel analyzed the final slurry sample by HPLC for the typical TPB decomposition products (i.e., TPB, 3PB, 2PB, 1PB, and phenol).

The Lab-scale Instrumented Demonstrations consisted of the following steps.

- Addition of Tank 48 slurry (pH 11 or 14) to stirred reactor.

- Add copper catalyst to stirred reactor (time zero).

- Heat to temperature.

- Start up off-gas analyzer.

- Begin metering in $30 \mathrm{wt} \%$ hydrogen peroxide.

- Continue adding hydrogen peroxide as needed.

- Add additional copper catalyst as needed. 


\section{RESULTS}

The primary objective of the testing was to measure the extent of TPB decomposition. In addition, analysis of the liquid and vapor were completed to understand and quantify the decomposition products present during the reaction. At the completion of the testing, measurements were performed to provide a gross measure of the general corrosion rate to the carbon steel reaction vessel.

\subsection{TPB Decomposition}

Two methods were used to determine the extent of TPB decomposition. The first analytical method utilized High Performance Liquid Chromatography (HPLC) to directly measure the TPB ion concentration. The second method looked for the ingrowth of $\mathrm{K}$ and $\mathrm{B}$ in filtered samples to track the decomposition of the TPB.

\subsubsection{HPLC}

For the pH 11 experiment, the final slurry TPB concentration was less than $10 \mathrm{mg} / \mathrm{L}$, the detection limit for this sample. This indicates the TPB was completely destroyed during the testing. For the $\mathrm{pH} 14$ experiment, the final slurry TPB concentration was 1,310 mg/L. For the $\mathrm{pH} 14$ experiment, the initial TPB concentration after including the peroxide dilution equaled 1,690 mg/L. This equates to $22 \%$ TPB decomposition for the $\mathrm{pH} 14$ experiment.

\subsection{2 $\mathrm{K}, \mathrm{B}$ ingrowth}

For the $\mathrm{pH} 11$ experiment, the $\mathrm{K}$ concentration in the filtrate exceeded the K concentration in the slurry for a calculated 100\% TPB decomposition due to analytical variance. The calculated TPB decomposition was 95\% based on the B analyses. These analyses confirm complete destruction of TPB in the $\mathrm{pH} 11$ experiment. Table 4.1 summarizes the data.

Table 4.1 - TPB Decomposition Based on Results of pH 11 Filtrate and Slurry Samples [10-28-04]

\begin{tabular}{|c|c|c|c|c|}
\hline $\begin{array}{c}\text { Sample ID } \\
\text { Analyte }\end{array}$ & $\begin{array}{c}\text { Filtrate } \\
\text { P11F-10/28/04 }\end{array}$ & $\begin{array}{c}\text { Digested Slurry } \\
\text { P11S-10/28/04 }\end{array}$ & $\begin{array}{c}\text { Predicted } \\
\text { Slurry } \\
\text { Composition }\end{array}$ & $\begin{array}{c}\text { \% TPB } \\
\text { Decomposition }\end{array}$ \\
\hline $\begin{array}{c}\text { ICP-ES B, } \\
\text { mg/L }\end{array}$ & 345 & 363 & 403 & $95 \%$ \\
\hline $\begin{array}{c}\text { ICP-ES K, } \\
\text { mg/L }\end{array}$ & 1470 & 1320 & 1550 & $100 \%$ \\
\hline AA K, mg/L & 1550 & NA & 1550 & $100 \%$ \\
\hline
\end{tabular}

Table 4.2 contains the results for the $\mathrm{pH} 14$ experiment. For the $\mathrm{pH} 14$ experiment, $10-20 \%$ decomposition was noted based on the filtrate and slurry values. The percentage decomposition is calculated by comparing the filtrate concentration to the predicted slurry composition. The prediction is used as the measured slurry TPB concentration was significantly lower than expected, likely due to a slurry sample that was low in insoluble solids. 
WSRC-TR-2005-00114

Revision 0

Table 4.2 - TPB Decomposition Based on Results of pH 14 Filtrate and Slurry Samples [10-28-04]

\begin{tabular}{|c|c|c|c|c|}
\hline $\begin{array}{c}\text { Sample ID } \\
\text { Analyte }\end{array}$ & $\begin{array}{c}\text { Filtrate } \\
\text { P14F-10/28/04 }\end{array}$ & $\begin{array}{c}\text { Corrected Starting } \\
\text { Filtrate } \\
\text { Composition }\end{array}$ & $\begin{array}{c}\text { Predicted } \\
\text { Slurry } \\
\text { Composition }\end{array}$ & $\begin{array}{c}\text { \% TPB } \\
\text { Decomposition }\end{array}$ \\
\hline $\begin{array}{c}\text { ICP-ES B, } \\
\text { mg/L }\end{array}$ & 50.9 & 6.54 & 389 & $10.3 \%$ \\
\hline $\begin{array}{c}\text { ICP-ES K, } \\
\text { mg/L }\end{array}$ & 376 & 263 & 1687 & $7.9 \%$ \\
\hline AA K, mg/L & 321 & NA & 1687 & $4.1 \%$ \\
\hline
\end{tabular}

\subsubsection{HPLC}

A single HPLC analysis of a sample pulled on 10-28-04 gives a snapshot of the TPB and TPB decomposition products present in that sample. For the $\mathrm{pH} 11$ experiment, the concentration of $13 \mathrm{TPB}$ decomposition products was each less than $10 \mathrm{mg} / \mathrm{L}$ based on a 10-28-04 slurry sample, the detection limit for this sample. As a result, not only was the TPB destroyed, but so were all of the typical decomposition products. If any of these species formed, they were destroyed before the sample was pulled. The one exception is biphenyl, a solid that sublimes (changes state from solid to vapor without forming a liquid). No biphenyl was left in the liquid but biphenyl crystals formed on the colder vessel lid and slowly migrated up the off-gas line. By the completion of the run, the biphenyl crystals had "disappeared" from the rig and off-gas lines. It should be noted that the slurry began the test with approximately $700 \mathrm{mg} / \mathrm{L}$ phenol. Phenol is easily oxidized at both $\mathrm{pH} 11$ and $\mathrm{pH} 14$ as none was remaining at the completion of the tests. Table 4.3 provides the results.

Table 4.3 - HPLC Analyses of 13 common TPB decomposition byproducts

\begin{tabular}{|c|c|c|c|}
\hline Analyte & Units & pH 11 & pH 14 \\
\hline 3PB & $\mathrm{mg} / \mathrm{L}$ & $<10$ & $<10$ \\
\hline 2PB & $\mathrm{mg} / \mathrm{L}$ & $<10$ & $<10$ \\
\hline PBA & $\mathrm{mg} / \mathrm{L}$ & $<10$ & $<10$ \\
\hline Phenol & $\mathrm{mg} / \mathrm{L}$ & $<10$ & $<10$ \\
\hline Nitrobenzene & $\mathrm{mg} / \mathrm{L}$ & $<10$ & $<10$ \\
\hline Nitrosobenzene & $\mathrm{mg} / \mathrm{L}$ & $<10$ & $<10$ \\
\hline 4phenylphenol & $\mathrm{mg} / \mathrm{L}$ & $<10$ & $<10$ \\
\hline 2phenylphenol & $\mathrm{mg} / \mathrm{L}$ & $<10$ & $<10$ \\
\hline Diphenylamine & $\mathrm{mg} / \mathrm{L}$ & $<10$ & $<10$ \\
\hline Biphenyl & $\mathrm{mg} / \mathrm{L}$ & $<10$ & 10 \\
\hline o-terphenyl & $\mathrm{mg} / \mathrm{L}$ & $<10$ & $<10$ \\
\hline m-terphenyl & $\mathrm{mg} / \mathrm{L}$ & $<10$ & $<10$ \\
\hline p-terphenyl & $\mathrm{mg} / \mathrm{L}$ & $<10$ & $<10$ \\
\hline
\end{tabular}




\subsubsection{Semivolatile and Volatile Organic Analyses}

A single Gas Chromatography - Mass Spectroscopy (GC-MS) analysis of a sample pulled on 10-28-04 gives a snapshot of the volatile and semivolatile organic species present in that sample. The $\mathrm{pH} 11$ slurry was analyzed by two methods to search for any remaining semivolatile or volatile organic species. No organic species were identified using Volatile Organic Analysis (VOA), including benzene. Three organic species were identified using Semi Volatile Organic Analysis (SVOA): p-terphenyl, quaterphenyl, and Phenol, 3-dimethylamino. Table 4.4 lists the results.

Table 4.4 - SVOA detectable analytes at pH 11
\begin{tabular}{|l|c|}
\hline Analyte & Concentration, mg/L \\
\hline p-Terphenyl & 11 \\
\hline Quaterphenyl & 3 \\
\hline Phenol, 3-dimethylamino & 2 \\
\hline
\end{tabular}

\subsubsection{Total Organic Carbon (TOC)/Total Inorganic Carbon (TIC)}

A single analysis of a sample pulled on 10-28-04 shows the inorganic and organic carbon present in that sample. The slurry was analyzed by two methods to search for any remaining inorganic (primarily carbonate) or organic species. The pH 11 slurry had a TIC of $2760 \mathrm{mg} / \mathrm{L}$ and a TOC of $1160 \mathrm{mg} / \mathrm{L}$. The measured TIC is equivalent to $0.230 \mathrm{M}$ carbonate if the entire TIC is carbonate.

\subsubsection{Ion Chromatography (IC) Anions}

A single analysis of a sample pulled on 10-28-04 measured the anions present in that sample. Formate and oxalate are two of the anions in the IC analytical suite. Neither formate nor oxalate is added as part of the simulant so any oxalate or formate present at the end apparently formed during testing, although it also could have formed during the prior hydrolysis experiment. Formate is $26.7 \% \mathrm{C}$ by mass and oxalate is 27.3\% C by mass. The calculated carbon mass from these two organic species is $820 \mathrm{mg} / \mathrm{L}$. This agrees reasonably with the $1160 \mathrm{mg} / \mathrm{L}$ TOC measured by TIC/TOC. It should also be noted that the large increase in nitrate (comparing $\mathrm{pH} 14$ to $\mathrm{pH} 11$ ) is due to the acidification of the sample with nitric acid. Also, about half of the nitrite was consumed (either due to acidification or oxidation) during testing. This indicates that the nitrite (a corrosion inhibitor) is fairly stable during testing. Table 4.5 contains the results. 
Table 4.5 - Anion Results

\begin{tabular}{|c|c|c|c|}
\hline Analyte & $\mathrm{pH} 11$ & $\mathrm{pH} 14$ & Units \\
\hline $\mathrm{F}^{-}$ & $<13$ & $<19$ & $\mathrm{mg} / \mathrm{L}$ \\
\hline $\mathrm{HCO}_{2}{ }^{-}$ & 424 & 162 & $\mathrm{mg} / \mathrm{L}$ \\
\hline $\mathrm{Cl}^{-}$ & 94 & 136 & $\mathrm{mg} / \mathrm{L}$ \\
\hline $\mathrm{NO}_{2}{ }^{-}$ & 8,600 & 15,400 & $\mathrm{mg} / \mathrm{L}$ \\
\hline $\mathrm{Br}^{-}$ & $<100$ & $<100$ & $\mathrm{mg} / \mathrm{L}$ \\
\hline $\mathrm{NO}_{3}{ }^{-}$ & 72,800 & 11,100 & $\mathrm{mg} / \mathrm{L}$ \\
\hline $\mathrm{PO}_{4}{ }^{3-}$ & 391 & 1,210 & $\mathrm{mg} / \mathrm{L}$ \\
\hline $\mathrm{SO}_{4}{ }^{2-}$ & 1,150 & 1,160 & $\mathrm{mg} / \mathrm{L}$ \\
\hline $\mathrm{C}_{2} \mathrm{O}_{4}{ }^{2-}$ & 2,580 & 1,130 & $\mathrm{mg} / \mathrm{L}$ \\
\hline
\end{tabular}

\subsubsection{Filtrate $\mathbf{p H}$}

A pH probe was operational throughout $\mathrm{pH} 11$ experiment. Filtrate samples were analyzed for $\mathrm{pH}$ as a confirmation for both experiments. The calibration of the $\mathrm{pH}$ probe slowly degraded during testing. No attempt was made to recalibrate as that would upset the off-gas measurements. The $\mathrm{pH}$ dropped as low as $\mathrm{pH} 9.1$ during the $\mathrm{pH} 11$ experiment. Much of the $\mathrm{pH}$ drop likely resulted from the two additions of copper catalyst (a $467 \mathrm{mg} / \mathrm{L} \mathrm{CuSO}_{4} \cdot 5 \mathrm{H}_{2} \mathrm{O}$ concentration has a $\mathrm{pH}$ of 4.0 ). The $\mathrm{pH}$ profile resembled that expected for a Fenton reaction where the $\mathrm{pH}$ drops due to the production of organic acids and later rises due to destruction of these organic acids. $\mathrm{pH}$ can be controlled through the addition of sodium hydroxide during processing but no attempt at $\mathrm{pH}$ control occurred in these experiments. The $\mathrm{pH}$ remained above 14 throughout the $\mathrm{pH} 14$ experiment. Figure 4.1 displays the $\mathrm{pH}$ data for the $\mathrm{pH} 11$ experiment. 
WSRC-TR-2005-00114

Revision 0

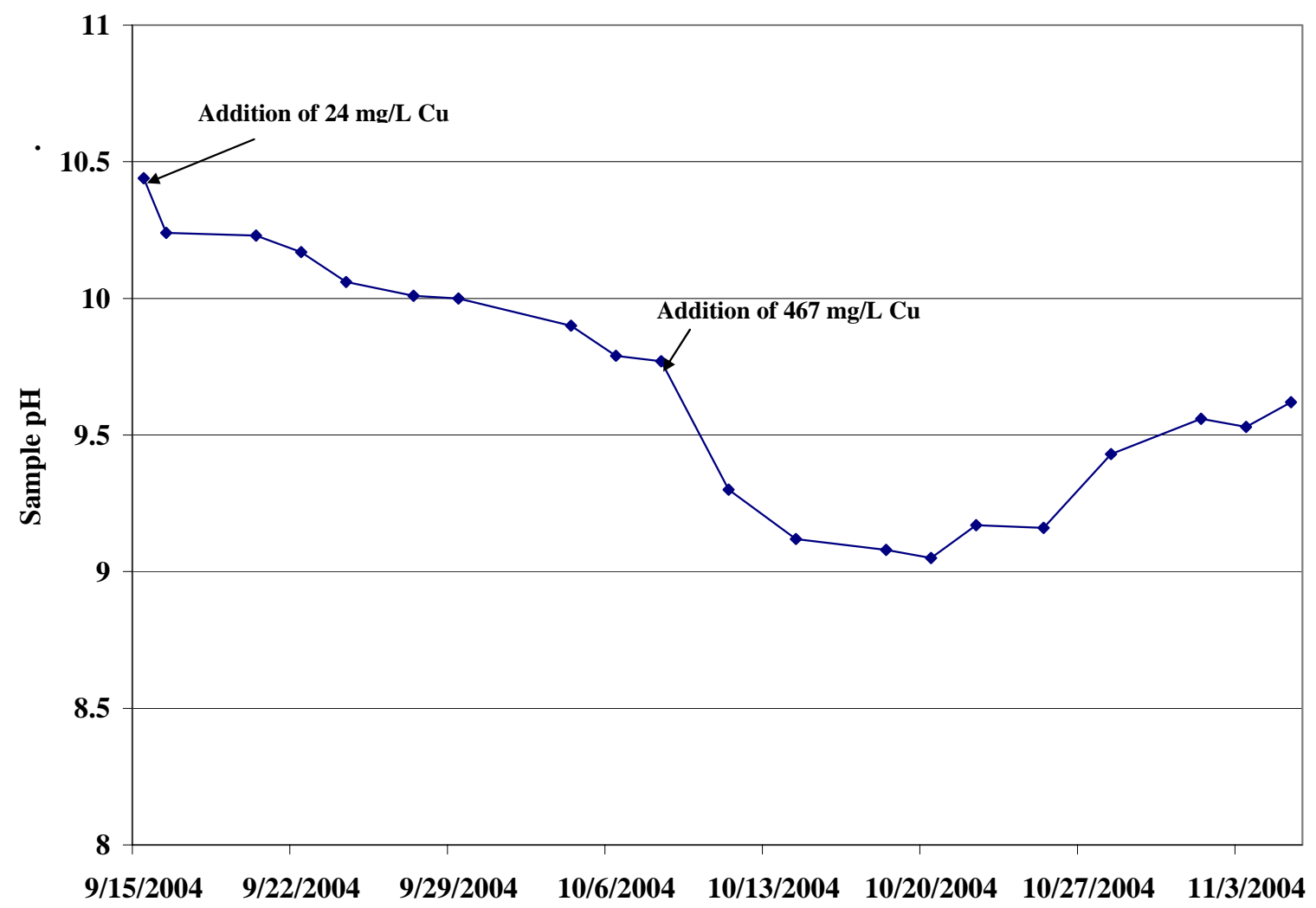

Figure 4.1 - pH Profile Throughout pH 14 Experiment

\subsection{Off-gas Measurements}

Flammability control in Tank $48 \mathrm{H}$ is currently controlled by minimizing the concentration of fuel (benzene) and oxidant (oxygen) in Tank 48H. To measure the oxygen and benzene concentration during the experiments, personnel used Gas Chromatographs (Agilent microGCs) for off-gas analysis both with two columns. The first column is a molecular sieve (Agilent G2801-60510 MolSieve 5A PLOT, $10 \mathrm{~m}$ $0.32 \mathrm{~mm}$ ) to analyze for hydrogen, oxygen, and nitrogen using a thermal conductivity detector. The second column is an organic column (Agilent OV-73) to analyze for benzene, using a thermal conductivity detector.

Identical methods were set up for both GCs. Each GC was calibrated using calibration standards for hydrogen, nitrogen, oxygen, and benzene before the experiments began. A calibration check occurred for each GC after 3 weeks. In addition, the GCs were baked out twice during testing to remove moisture and carbon dioxide that accumulated in the columns.

The GCs were set up to measure the off-gas composition from each vessel each hour. The sample pump ran for 90 seconds prior to each injection to ensure each sample was representative. Details concerning the calibration and operation of the GCs are summarized in the laboratory notebook.

\subsubsection{Benzene Analysis}

Analysis for benzene is needed to quantify the benzene produced and assess flammability issues. The Lower Flammability Limit (LFL) for benzene is $1.2 \mathrm{vol} \%$ in air. At a benzene concentration less than $1.2 \mathrm{vol} \%$, insufficient fuel exists to support combustion. The benzene concentration was below $25 \%$ of the LFL throughout the testing. At $\mathrm{pH}$ 11, benzene spikes occurred while increasing the temperature from 
$35^{\circ} \mathrm{C}$ to $45^{\circ} \mathrm{C}$, from $45^{\circ} \mathrm{C}$ to $55^{\circ} \mathrm{C}$, and from $55^{\circ} \mathrm{C}$ to $75^{\circ} \mathrm{C}$. The maximum benzene concentration occurred immediately after the temperature increased from $55^{\circ} \mathrm{C}$ to $75^{\circ} \mathrm{C}$ due to the increased mass transfer of benzene from the slurry to vapor. However, the steady state benzene concentration quickly dropped back to a concentration of well less than $2 \mathrm{mg} / \mathrm{L} / \mathrm{hr}$ benzene ( $\sim 100 \mathrm{ppm}_{\mathrm{v}}$ benzene). These peaks are influenced by the rate of heating and would likely have been much shorter and broader for a slow temperature ramp, similar to what would be expected in Tank $48 \mathrm{H}$. Figure 4.2 contains the data for the pH 11 experiment.

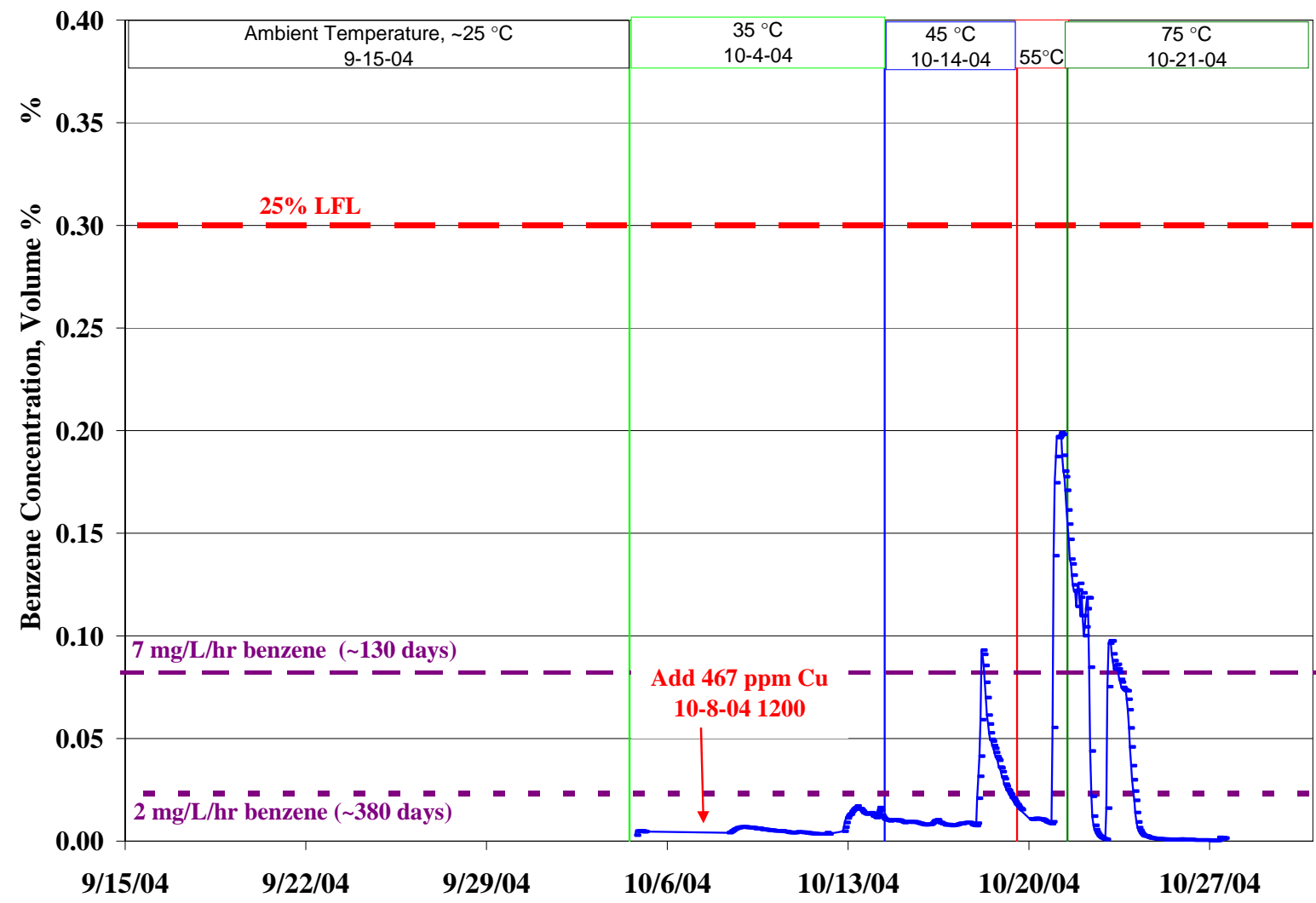

Figure 4.2 - Benzene Concentration During pH 11 Experiment

At pH 14, benzene spikes occurred while increasing the temperature from $35^{\circ} \mathrm{C}$ to $45^{\circ} \mathrm{C}$, and from $45^{\circ} \mathrm{C}$ to $55^{\circ} \mathrm{C}$. The maximum benzene concentration occurred immediately after the temperature increased from $55^{\circ} \mathrm{C}$ to $75^{\circ} \mathrm{C}$ due to the increased mass transfer of benzene from the slurry to vapor and possibly increased reactivity of the intermediates. However, the steady state benzene concentration soon dropped back to a concentration of well less than $2 \mathrm{mg} / \mathrm{L} / \mathrm{hr}$ benzene ( $\sim 100 \mathrm{ppm}_{\mathrm{v}}$ benzene). Figure 4.3 shows the data from the $\mathrm{pH} 14$ test. 
Figure 4.3 - Benzene Concentration during Portion of pH 14 Experiment

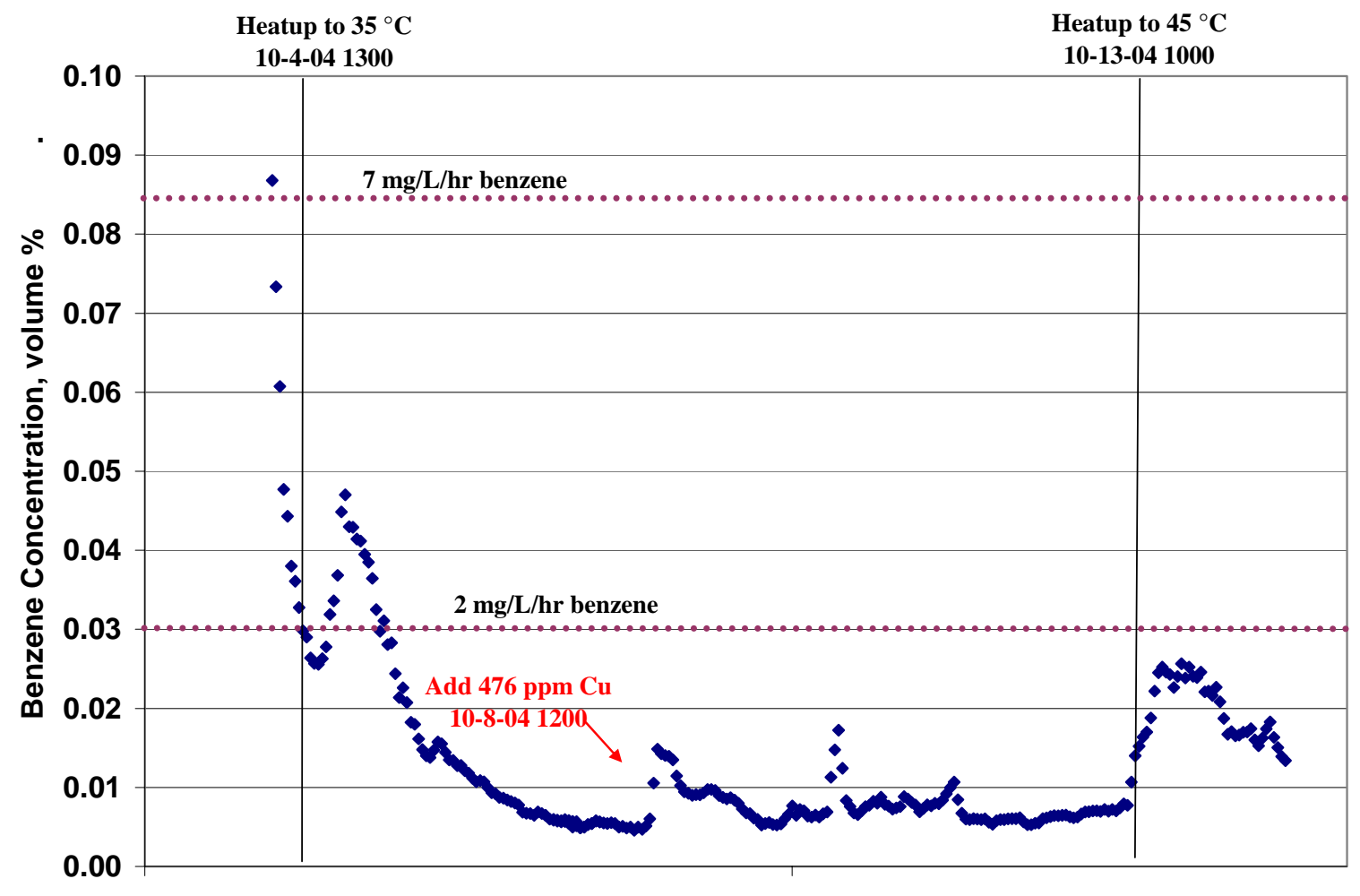

04-Oct-04

11-Oct-04

\subsubsection{Oxygen Analysis}

Analysis for oxygen is needed to quantify the oxygen produced due to decomposition of hydrogen peroxide and assess flammability issues (i.e., whether minimum oxidant control is sustained during the reaction). The air and nitrogen purge provided 5\% oxygen and $95 \%$ nitrogen to the inlet of the vessels. The oxygen concentration could increase to as much as $9.87 \mathrm{vol} \%$ if all of the hydrogen peroxide decomposed to water and oxygen. The Minimum Oxygen Concentration (MOC) for benzene is $11.4 \mathrm{vol} \%$. At an oxygen concentration less than $11.4 \mathrm{vol} \%$, insufficient oxygen exists to support combustion. The oxygen concentration remained below $60 \%$ of the MOC throughout the testing, with the exception of a few data points taken after maintenance of the equipment introduced room air ( $21 \%$ oxygen) into the off-gas. The oxygen concentration exceeded $6.9 \mathrm{vol} \%$, the Tank $48 \mathrm{H}$ oxygen limit, for much of the testing. The oxygen concentration can be controlled by decreasing the hydrogen peroxide addition rate. Figure 4.4 shows the data for the $\mathrm{pH} 11$ experiment. 
WSRC-TR-2005-00114

Revision 0

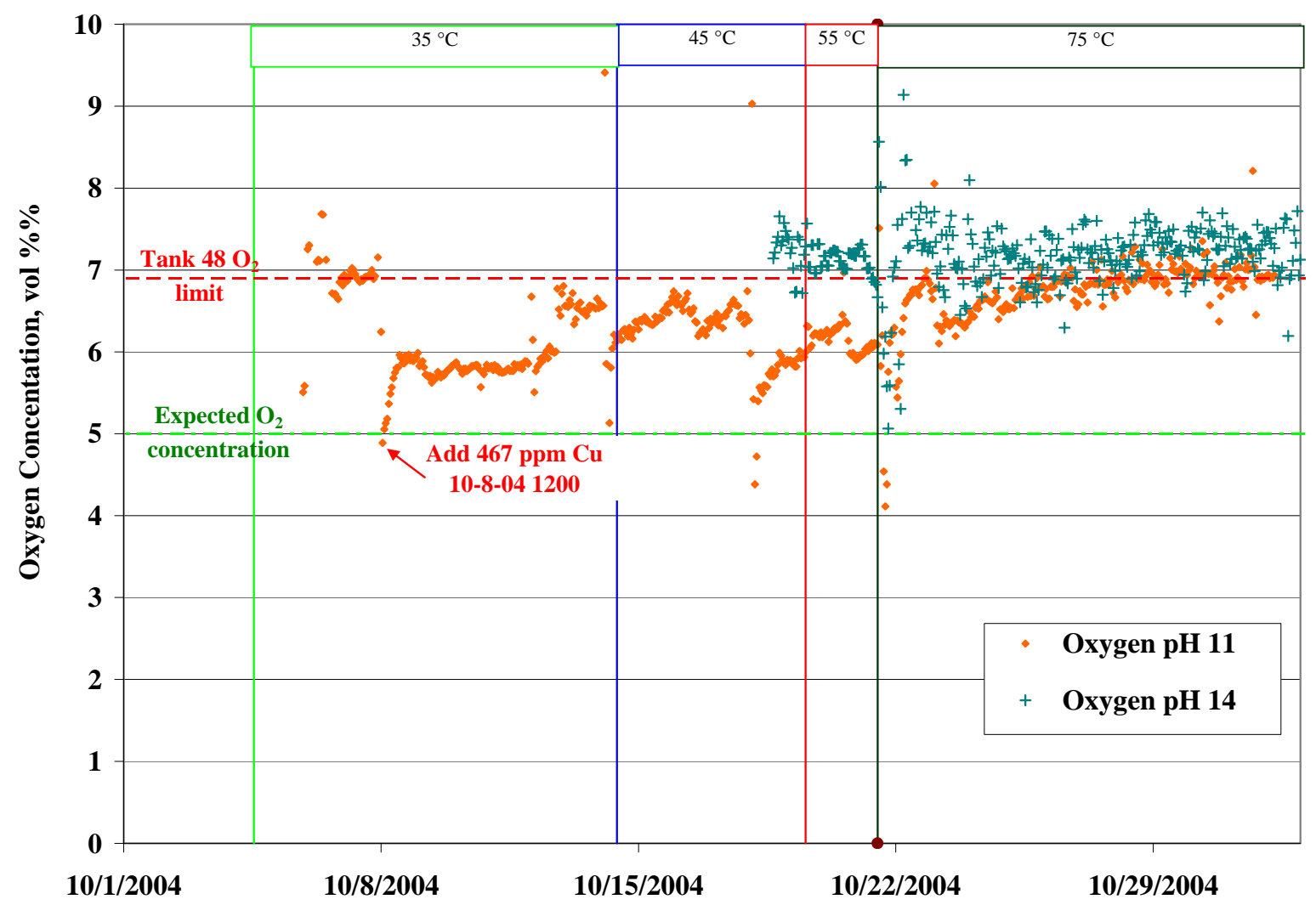

Figure 4.4 - Oxygen Concentration during Experiments

\subsection{Impact of Copper Addition}

The addition of $1.1064 \mathrm{~g}$ of $\mathrm{CuSO}_{4} \cdot 5 \mathrm{H}_{2} \mathrm{O}(0.315 \mathrm{~g}$ Cu added to $674 \mathrm{~mL}$ of slurry) led to a $467 \mathrm{mg} / \mathrm{L}$ increase in the copper concentration on 10-8-2004. The copper addition correlates strongly with the destruction of TPB for the following reasons. First, no detectable TPB decomposition occurred before the addition of copper. The soluble $\mathrm{K}$ and $\mathrm{B}$ concentration increased after addition of copper, indicating that the TPB was being consumed. Second, the off-gas oxygen concentration dropped from a steady value of $7 \mathrm{vol} \%$ to $6 \mathrm{vol} \%$ after the addition of the $467 \mathrm{mg} / \mathrm{L}$ copper. If no peroxide is added, the expected oxygen concentration is $5 \mathrm{vol} \%$. (i.e., the concentration entering the vessel) If none of the peroxide is oxidizing the TPB, it will react with itself decomposing to oxygen and water (explaining the $7 \mathrm{vol} \%$ oxygen during the early part of the testing). Upon copper addition, the oxygen concentration dropped to $\sim 6$ vol \%, indicative that approximately half of the peroxide was being consumed in oxidation reactions. Figure 4.5 summarizes the measured benzene concentration and the calculated TPB decomposition based on filtrate K analyses. Figure 4.6 summarizes the oxygen concentration after the addition of $467 \mathrm{mg} / \mathrm{L}$ copper. Note the drop in oxygen concentration after the additional copper addition, indicative of more efficient peroxide utilization. 
WSRC-TR-2005-00114

Revision 0

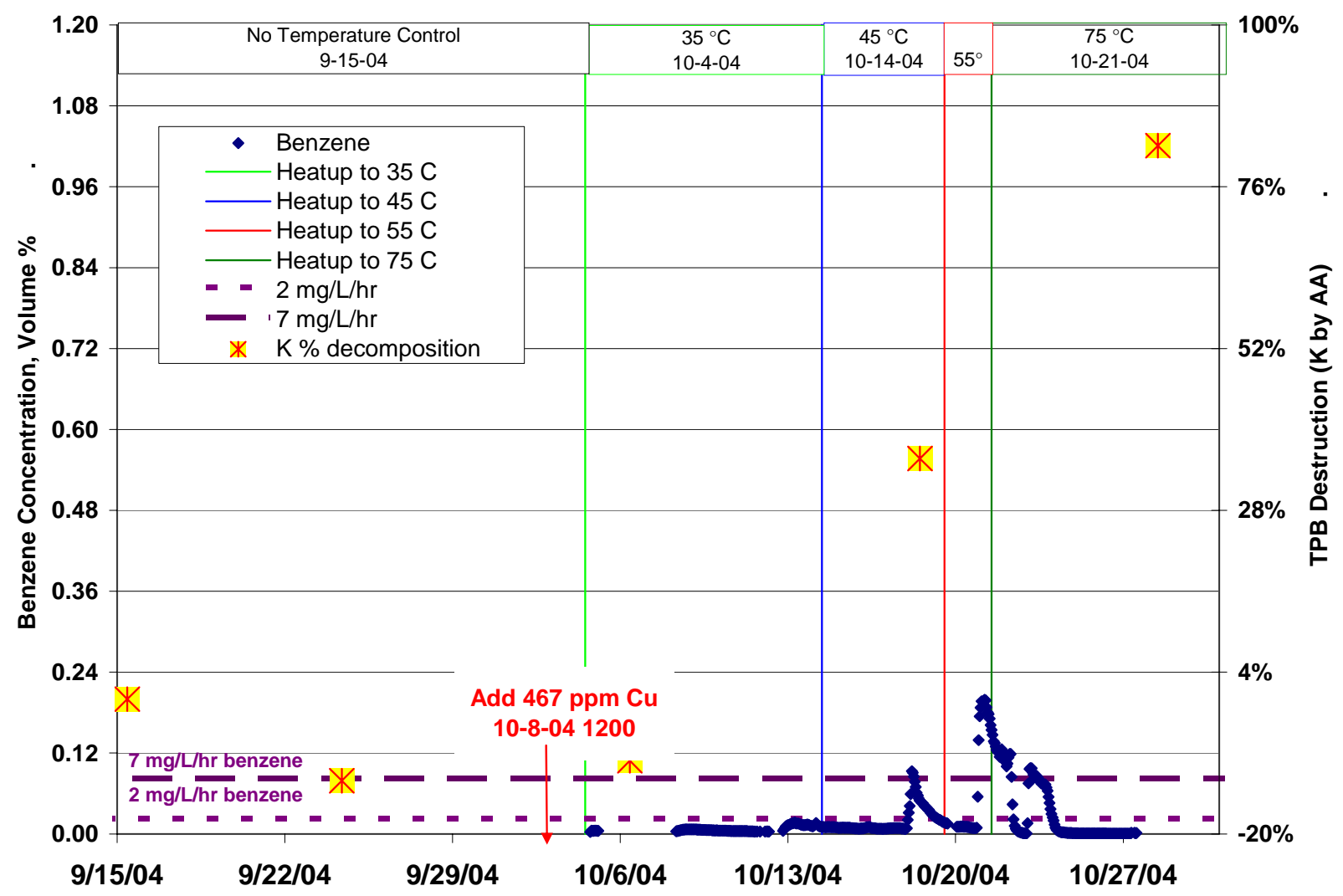

Figure 4.5 - pH 11 Experiment Calculated TPB Destruction and Benzene Concentration 
WSRC-TR-2005-00114

Revision 0

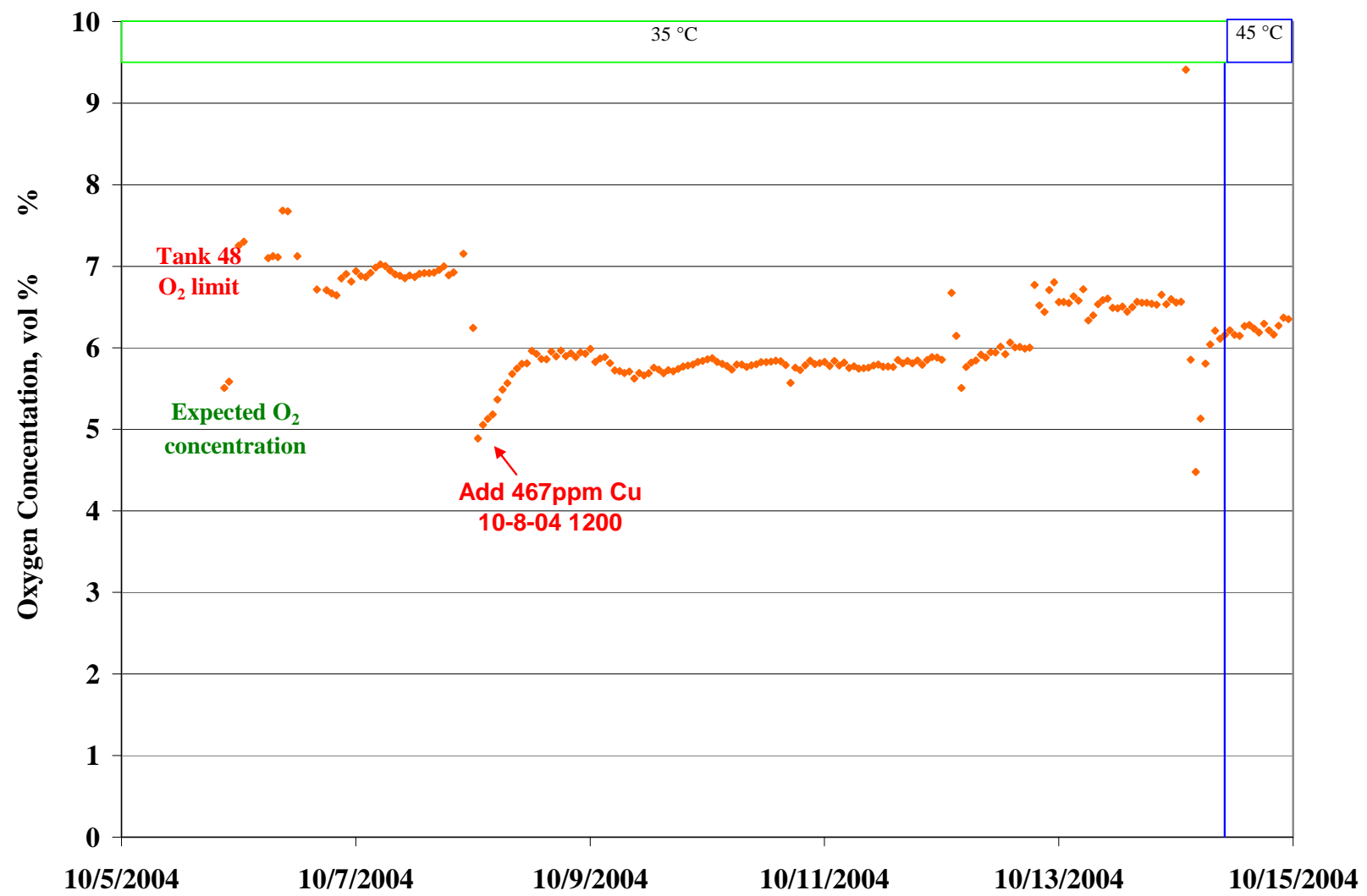

Figure 4.6 - Oxygen Concentration after Addition of 467 mg/L Copper Catalyst

\subsection{Corrosion Testing}

Personnel measured corrosion of the carbon steel vessels at the end of each experiment. The demonstrations used carbon steel reaction vessels to serve as crude corrosion coupons. Each vessel was fabricated by welding a 3-1/2" schedule 10 carbon steel pipe cap to 3-1/2” schedule 10 carbon steel pipe. Three internal baffles improved mixing. The inside carbon steel surfaces were not polished before testing as is traditional with corrosion coupons. The outside of each vessel was painted with Krylon paint to prevent corrosion during exposure in the silicon oil bath.

After testing, the vessels were drained, rinsed with DI water and cleaned with acetone prior to beginning the corrosion test. The vessels were weighed before and after each step with the results summarized in Table 4.6. 
WSRC-TR-2005-00114

Revision 0

Table 4.6 - Corrosion Data

\begin{tabular}{|l|c|c|}
\hline Data & $\mathrm{pH} \mathrm{11}$ & $\mathrm{pH} 14$ \\
\hline Liquid Height, cm & 6.57 & 6.57 \\
\hline Vessel height, cm & 17.15 & 17.15 \\
\hline Vessel diameter, cm & 9.84 & 9.84 \\
\hline Density, g/cm ${ }^{3}$ & 7.86 & 7.86 \\
\hline Conversion Factor K, mil/year & $3.45 \mathrm{E}+06$ & $3.45 \mathrm{E}+06$ \\
\hline Calculated Area, cm ${ }^{2}$ & 606.2 & 606.2 \\
\hline Calculated Volume, cm ${ }^{3}$ & 1304.20 & 1304.20 \\
\hline Mass Loss, W, g & 6.82 & 5 \\
\hline & $9 / 15 / 2004$ & $9 / 15 / 2004$ \\
Start Date & $10: 09$ & $13: 00$ \\
\hline & $11 / 9 / 2004$ & $12 / 21 / 2004$ \\
Finish Date & $13: 00$ & $13: 00$ \\
\hline Time at exposure, h & 1322.85 & 2328 \\
\hline Corrosion Rate, mil/year & 3.73 & 1.56 \\
\hline
\end{tabular}

The corrosion measurement followed ASTM G1-901, Standard Practice for Preparing, Cleaning, and Evaluating Corrosion Test Specimens, reapproved 1999. As per the standard, Clarke's solution (1-L 40 wt \% or $13 \mathrm{M} \mathrm{HCl}, 20 \mathrm{~g}$ antimony trioxide, and $50 \mathrm{~g}$ stannous chloride) was prepared in a 2-L poly bottle. The testing was completed at room temperature. Each vessel was soaked on five successive occasions (soak \#1, soak \#2, etc.). After each soak, the Clarke's solution was filtered with $0.45 \mu \mathrm{m}$ syringe filter and returned to the original poly bottle. The vessel was drained, rinsed with DI water, and air dried. The vessel was weighed after drying. Table 4.6 contains the data. The corrosion rate is calculated based on the following formula:

Corrosion rate, $\mathrm{mil} / \mathrm{y}=(3.45 \mathrm{E} 6 * \mathrm{~W}) /(\mathrm{A} * \mathrm{~T} * \mathrm{D})$

$\mathrm{W}=$ mass loss, grams; $\mathrm{A}=$ Cross Sectional Area, $\mathrm{cm}^{2} ; \mathrm{T}=$ time of exposure, hours; $\mathrm{D}=$ density, $\mathrm{g} / \mathrm{cm}^{3}=$ $7.86 \mathrm{~g} / \mathrm{cm}^{3} . \quad A=\Pi^{*}\left(d^{2} / 4+d^{*} h\right), d=9.84 \mathrm{~cm}, \mathrm{~h}=17.15 \mathrm{~cm}, \mathrm{~A}=606.23 \mathrm{~cm}^{2}$. 
WSRC-TR-2005-00114

Revision 0

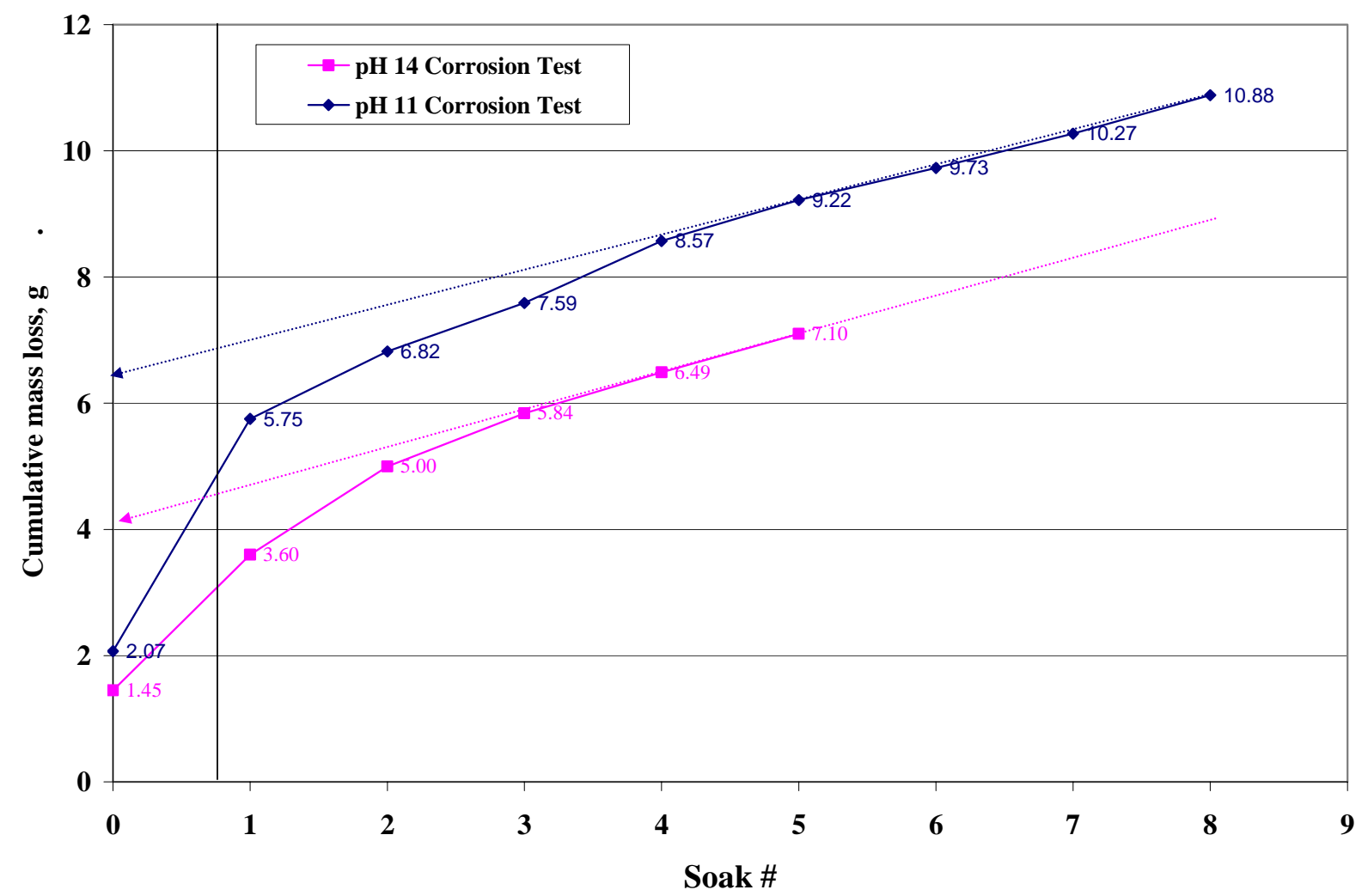

Figure 4.7 - pH 11 Corrosion Test Data for Multiple Soaks with Clarke's Solution

Based on the above equation and the data from Table 4.6, the general corrosion rate is $3.7 \mathrm{mil} / \mathrm{year}$ for the $\mathrm{pH} 11$ experiment and 1.6 mil/year for the $\mathrm{pH} 14$ experiment.

Previous Tank $48 \mathrm{H}$ corrosion testing relied on electrochemical tests of carbon steel (Type III waste tank steel is ASTM A537 class 1) test specimens in simulated waste solutions. Tests at $\mathrm{pH} 11$ and between 45 and $65{ }^{\circ} \mathrm{C}$ revealed a relatively low general corrosion rate of 5 mils per year ( 0.005 inches per year). The threshold for reporting wall-thinning in the in-service inspection program for high-level waste tanks is $10 \%$ of wall thickness (e.g., 50 mils’ loss in 0.5 -inch-thick plate). The 3.7-mil/y loss would also not significantly affect the cooling coils, whose wall thickness is about 150 mils. The experiments did not provide a measure of pitting corrosion.

\subsection{Mass Balance}

A running mass balance was maintained throughout the experiments since the reactor volume changed from peroxide additions and sample removal. The combined impact is a slow dilution of the slurry. The concentration of TPB, B, and K throughout the experiment are corrected for the dilution. Table 4.7 summarizes the impact for the $\mathrm{pH} 11$ Experiment. 
WSRC-TR-2005-00114

Revision 0

Table 4.7 - Volume Balance for pH 11 Experiment

\begin{tabular}{|l|c|}
\hline Starting Volume & $600 \mathrm{~mL}$ \\
\hline Added $\mathrm{H}_{2} \mathrm{O}_{2}$ & $+320 \mathrm{~mL}$ \\
\hline 20 9-mL samples removed & $-180 \mathrm{~mL}$ \\
\hline Predicted and Final Volume & $740 \mathrm{~mL}$ \\
\hline
\end{tabular}

A spreadsheet was used to account for the removal of samples and addition of hydrogen peroxide. The mass balance results are summarized in the Laboratory notebook for the $\mathrm{pH} 11$ and $\mathrm{pH} 14$ experiments.

\subsection{Carbon Balance}

One of the most compelling advantages of an oxidation process is minimization of benzene generation during decomposition of the tetraphenylborate. Personnel used the analyses of liquid samples and off-gas to identify and quantify the decomposition products of TPB. Ideally, all of the TPB would decompose to carbon dioxide. However, carbon dioxide was not measured in the off-gas. Table 4.8 summarizes the information for the $\mathrm{pH} 11$ experiment.

Table 4.8 - pH 11 Carbon Balance

\begin{tabular}{|c|c|c|c|c|}
\hline & Before & After & Change & \\
\hline Component & $\begin{array}{c}C \text { mass } \\
\mathrm{g}\end{array}$ & $\begin{array}{c}C \text { mass } \\
\mathrm{g}\end{array}$ & $\begin{array}{c}C \text { mass } \\
\mathrm{g}\end{array}$ & $\begin{array}{c}\text { Final } \\
\text { Slurry as } \\
\% \\
\text { Original } \\
\text { Carbon }\end{array}$ \\
\hline TPB & 6.32 & 0.00 & -6.32 & $0 \%$ \\
\hline Biphenyl & 0.36 & 0.00 & -0.36 & $0 \%$ \\
\hline Phenol & 0.45 & 0.00 & -0.45 & $0 \%$ \\
\hline Total Organic Carbon & 7.13 & 0.00 & -7.13 & $0 \%$ \\
\hline Formate & 0.00 & 0.20 & 0.20 & $2.8 \%$ \\
\hline Oxalate & 0.00 & 1.26 & 1.26 & $17.7 \%$ \\
\hline benzene $(\mathrm{g})$ & 0.03 & 0.42 & 0.39 & $5.4 \%$ \\
\hline Carbonate & 3.31 & 3.90 & 0.60 & $8.4 \%$ \\
\hline p-terphenyl & 0.00 & 0.01 & 0.01 & $0.2 \%$ \\
\hline Quaterphenyl & 0.00 & 0.00 & 0.00 & $0.1 \%$ \\
\hline phenol, 3-dimethylamino & 0.00 & 0.00 & 0.00 & $0.0 \%$ \\
\hline Total & 10.47 & 5.80 & -4.66 & $34.6 \%$ \\
\hline
\end{tabular}

The data demonstrates that the organic species, TPB, biphenyl and phenol were all completely destroyed. It also demonstrates that $5.4 \%$ of the organic carbon decomposed to benzene. Small quantities of p-terphenyl, quaterphenyl, and phenol, 3-dimethylamino were present just above their detection limits and accounted for $<0.3 \%$ of the decomposition products. Two major species produced were oxalate and formate. The remainder of the organic species likely decomposed to $\mathrm{CO}_{2}$ (personnel did not measure $\mathrm{CO}_{2}$ formation). 


\section{CONCLUSIONS}

Two Lab-scale Instrumented Demonstrations focused on TPB decomposition and off-gas generation with Tank $48 \mathrm{H}$ simulant starting at $\mathrm{pH} 11$ and 14 . The experiment at $\mathrm{pH} 11$ led to complete and fast TPB decomposition (i.e., total TPB decomposition complete in $<3$ weeks), complete oxidation of TPB decomposition byproducts, including benzene. The experiment resulted in an approximately $75 \%$ increase in waste volume

The experiment at $\mathrm{pH} 14$ led to slower TPB decomposition - approximately 15\% decomposition in 9 weeks. The volume roughly doubled in during testing so this process is not feasible in Tank $48 \mathrm{H}$ without a better catalyst system.

Personnel made corrosion measurements using the carbon steel reaction vessel as a large corrosion coupon after the experiments. The general corrosion rate equaled 3.7 mil/year at $\mathrm{pH} 11$ and $1.6 \mathrm{mil} /$ year at $\mathrm{pH}$ 14. The corrosion rate appears "manageable" based on general corrosion rates. Corrosion control might occur through the addition of a corrosion control inhibitor (nitrite) - since this species reacted slowly in the presence of peroxide - during processing while minimizing the reaction temperature and reaction duraration.

Several issues remain which must be resolved prior to implementation of this technology.

1. The test at $\mathrm{pH} 11$ used a Tank $48 \mathrm{H}$ waste simulant. Future testing needs to be completed with Tank $48 \mathrm{H}$ waste to confirm these findings.

2. Earlier corrosion testing with Tank $48 \mathrm{H}$ simulant at an extremely fast (100x) hydrogen peroxide addition rate identified pitting of carbon steel as a potential issue. Direct measurements of pitting behavior are needed at the less aggressive conditions of this study.

3. The test at $\mathrm{pH} 11$ used a single peroxide addition rate (chosen to minimize testing time), at two copper catalyst concentrations, and at a $\mathrm{pH}$ lower than targeted.

\section{RECOMMENDATIONS/PATH FORWARD}

Further development of a copper catalyzed tetraphenylborate oxidation process is recommended. The issues identified above should be resolved through the following steps.

- Conduct a confirmatory test for the $\mathrm{pH} 11$ Experiment with actual waste from Tank 48H.

- Determine corrosion rate and measure pitting potential in carefully controlled corrosion experiments. The experiments should focus on pitting potential of the carbon steel tank and cooling coils.

- Develop a copper catalyzed tetraphenylborate oxidation flowsheet. The experiments should be completed in lab-instrumented experiments. Measure $\mathrm{CO}, \mathrm{CO}_{2}$, benzene, and oxygen in the offgas. 


\section{REFERENCES}

1 Philip E. Zapp and John I. Mickalonis, "Electrochemical Tests of Carbon Steel in Simulated Waste Containing Fenton’s Reagent”, WSRC-TR-2003-00445, Rev. 1, March 2004.

2 R. A. Adams, D. P. Lambert, R. C. Fowler, T. B. Peters, G. C. Winship, M. R. Norton, N. P. Malik, R. Bentley, “HLW TANK 48H Disposition Alternatives Identification Phase 1 Summary Report”, WSRC-RP-2002-00154, Revision 0, July 2002.

3 D. P. Lambert, T. B. Peters, M. J. Barnes, and S. D. Fink, “Task Technical and Quality Assurance Plan for Disposition of Tetraphenylborate in Tank 48H”, WSRC-RP-2004-00114, Rev. 0, February 2004.

$4 \quad$ Lambert, D. P., T. B. Peters, M. E. Stallings, and S. D. Fink. Development of Chemical Treatment Alternatives for Tetraphenylborate Destruction in Tank 48H, WSRC-MS-2002-00786, February 2003.

5 C. M. Jantzen, “Disposition of Tank 48H Organics by Fluidized Bed Stream Reforming (FBSR)”, WSRC-TR2003-00352, Rev. 0, September 18, 2003.

$6 \quad$ S. Bates, D. Marshall, D. Siemer, and N. Soelberg, “SRS Tank 48H Waste Steam Reforming Proof-of-Concept Test Results”, INEEL/EXT-03-01118, September 15, 2003.

7 D. P. Lambert, T. B. Peters, M. E. Stallings, P. Taylor, and S. D. Fink, "Closure Report, Process Development For Destruction Of Tetraphenylborate In SRS Tank 48H”, WSRC-TR-2003-00365, Rev. 0, August 28, 2003.

8 J Wilks and C Mitchell, “Chemical Oxidation of Tank 48 Simulant”, WMTD(03)P143, September 2003.

$9 \quad$ P. A. Taylor, “Treatment of SRS Tank 48H Simulants Using Fenton’s Reagent”, ORNL/TM-2003/262, November 2003.

10 R., A. Bajura, "Environmental Management Call for Proposals - Alternatives to Disposition of High-Level Waste Salt at the Savannah River Site”, January 10, 2001.

11 D. P. Lambert, T. B. Peters, M. J. Barnes, and S. D. Fink, “Copper Hydrolysis and Peroxide Oxidation Testing for the Decomposition of Tetraphenylborate in Tank 48H”, WSRC-TR-2004-00306, November 2004.

12 D. P. Lambert, T. B. Peters, M. J. Barnes, and S. D. Fink, “Copper Hydrolysis and Peroxide Oxidation Testing for the Decomposition of Tetraphenylborate in Tank 48H”, WSRC-TR-2004-00306, Rev. 0, November 2004.

13 T.B. Peters, D. P. Lambert, M. S. Hay, and S.D. Fink, “Operability Window Tests Using Tank 48H Samples”, WSRC-RP-2004-00281, September 25, 2004.

14 T. B. Peters, M. J. Barnes, and S. D. Fink, “Benzene Generation for Tk48H Waste Disposition”, WSRC-TR2004-00422, November 16, 2004.

15 Fire protection guide to hazardous materials, 13th ed. Edited by A.B. Spencer, et al. National Fire Protection Association, 2002. NFPA 325; NFPA 49; NFPA 491.

16 National Institute for Occupational Safety and Health Guidelines for benzene, 1988.

17 H. E. Shook and R. E. Eibling, "Proposed Reaction Mechanisms in Precipitate Hydrolysis: Trip Report”, DPST88-1026, December 8, 1988. 
18 Reference Library Peroxide Applications, http://www.h2o2.com/applications/industrialwastewater/fentonsReagent.html, 1/29/03.

19 Jerome, K. M., B. Riha, and B. B. Looney, "Final Report for Demonstration of In Situ Oxidation of DNAPL Using the Geo-Cleanse ${ }^{\circledR}$ Technology”, WSRC-TR-97-00283, 1997.

20 WSRC-NB-2004, 00148, Peroxide Assisted Experiments, Part 2.

21 D. P. Lambert, T. B. Peters, M. J. Barnes, and S. D. Fink, “Task Technical and Quality Assurance Plan for Disposition of Tetraphenylborate in Tank 48H”, WSRC-RP-2004-00114, Rev. 1, May 2004. 